consequence of close linguistic contact can also be pronounced divergent processes. This article focuses on morphological and wordformation changes that have significantly changed the grammatical properties of numerals in Slovak literary language, while in Czech they remained unchanged.

DOI: $10.31168 / 0459-6.07$

$$
\begin{array}{r}
\text { М. Г. Джонова (София, България), } \\
\text { С. И. Лесева (София, България), } \\
\text { Е. Ю. Иванова (Санкт-Петербург, Русия) }
\end{array}
$$

\title{
Инхоативни глаголи с дателен експериенцер в българския език ${ }^{1}$
}

В настоящата статията се прави синтактично описание на инхоативните глаголи от типа на домъчнее/дольчнява ми в съвременния български език. Те имат задължителен аргумент дателно местоимение със семантичната роля експериенцер и означават ново състояние на субекта. В деривационно отношение се свързват със съществителни, прилагателни или наречия за фризиологично, ментално или емоционално състояние, вж. (Радева 1993). В семантично отношение разглежданите глаголи съответстват на синтактичните конструкции с предикатив за състояние и дателно местоимение. В някои случаи те се свързват пряко с предикатива (зле ми е - призлее / призлява ми), а в други (студено - застудее / застудява ми, тьжно - дотьжее / доть-

1 Настоящият текст е резултат от изпълнението на научната програма на проекта «Онтология на ситуациите за състояние - лингвистично моделиране. Съпоставително изследване за български и руски», подкрепен от Фонд «Научни изследвания» в рамките на конкурса «Проекти по програма за двустранно сътрудничество - България - Русия 2019-2020 г.», договор № КП-06-П РУСИЯ-78 от 2020 г. и РФФИ (проект № 20-512-18005). 
жава $⿻)^{2}$ е налице връзка по-скоро със съществителното (mъга, студ), което мотивира съответния предикатив. Важна особеност на инхоативните глаголи за фризиологично или емоционално състояние е, че образуват видови двойки (глагол от свършен и глагол от несвършен вид) и че са винаги безлични, т. е. имат само форми за 3 л. ед. ч. и подложната позиция при тях остава винаги празна.

При изследването на инхоативните глаголи В. Недялков посочва, че те са начинателни глаголи, които са семантично (а в повечето случаи и словообразувателно) съотносими със стативи (непределни предикати, обозначаващи качество, състояние, положение в пространството). В рамките на инхоативните предикати авторът разглежда като отделна група глаголите за емоция и възприятие, при които начинателното значение указва момента на поява, възникване на ситуацията (Недялков 1987: 189). Според К. Иванова тези глаголи показват изменение на интензитета на действието от нула към наличие (Иванова 1974: 94).

Обект на настоящото изследване е възможността за образуване на инхоативни предикати от различните семантични групи статични предикативни конструкции и синтактичното описание на инхоативните предикати, като се отбелязват разликите със съответните статични предикативни конструкции.

Изследването се основава на данни от Българския национален корпус (БНК ${ }^{3}$, Koeva et al. 2012), примери от неофициална интернет комуникация, справка за глаголите в Официалния правописен речник (Мурдаров 2016) и в Речника на българския език (РБЕ 1977-2015).

2 По-нататьк в текста ще се споменават само корелатите от свършен вид, като наблюденията се отнасят и за двата глагола, което е онагледено и в част от примерите.

3 http://search.dcl.bas.bg/. 
В българския език инхоативните съответствия на статичните предикативни конструкции ${ }^{4}$ се образуват по два модела: със замяна на глагола съл в конструкцията с глагола стане / става, който означава преминаване в ново състояние (срв. топло ми е-става ми топло), и/или с префригиран глагол, мотивиран от предикативното наречие (срв. лошо ли е - става ли лошо - прилошава ли). При префигираните глаголи основният аргумент остава експериенцерът в дателен падеж и предикатът е безличен. В деривационно отношение инхоативните глаголи се образуват с конфикса до-(при-)/-ее (домбчнее/ дольчнява ми), а в някои случаи със за--/-ее и о-/ее (захладнее/захладнява ли, олекне / олеква ли) (Радева 1993). Инхоативни глаголи се образуват предимно от предикативите, означаващи фризиологично или емоционално състояние.

Таблица 1. Предикативи на -о/-е и техните инхоативни съответствия

\begin{tabular}{|l|l|}
\hline $\begin{array}{l}\text { Статична предикативна } \\
\text { конструкция с дат. клитика }\end{array}$ & $\begin{array}{l}\text { Инхоативен глагол } \\
\text { с дат. клитика }\end{array}$ \\
\hline хладно ми е & захладнее / захладнява ми \\
\hline студено ми е & $\begin{array}{l}\text { застудее / застудява ми, } \\
\text { достудее / достудява ми }\end{array}$ \\
\hline лошо ми е & прилошее / прилошава ми \\
\hline зле ми е & призлее / призлява ми \\
\hline леко ми е & олекне / олеква ми \\
\hline мъчно ми е & $\begin{array}{l}\text { домъчнее / домъчнява ми, } \\
\text { примъчнее / примъчнява ми }\end{array}$ \\
\hline тъжно ми е & дотъжее / дотъжава ми \\
\hline жал / жално ми е & дожалее / дожалява ми \\
\hline мило ми е & домилее / домилява ми \\
\hline скучно ми е & доскучае / доскучава ми \\
\hline криво ми е & докривее / докривява ми \\
\hline
\end{tabular}

4 За предикативите в български вж. (Рожновская 1956, Маслов 1982, Иванова 2016). 


\section{Глаголи за физиологично състояние}

Инхоативните глаголи за физиологично състояние застудее ми, захладнее ми, прилошее ми, призлее ми, олекне ми съответстват на статичните предикативни конструкции студено, хладно, лошо, зле, леко мие. Централният аргумент е дателното местоимение със семантичната роля експериенцер 5 . Вторият аргумент е предложна фраза със семантичната роля локатив ${ }^{6}$, означаващ частта от тялото, свързана с даденото усещане. Този аргумент се изразява с предложна фраза с предлога на (1), но са възможни и други локативни предлози, като зад (2):

1. Беше му прилошало на столаха <..> и това чувство се усилваше

2. Нещо ми захладня зад ушите, попипах - кргв.

При инхоативните глаголи прилошее ми и призлее ми по-често се изразява експлицитно и трети аргумент - стимулът за съответното физиологично състояние. Този аргумент се изразява с предложна фраза с предлога от (3), като се срещат и примери с предлога заради (4):

3. Казах ти, че от уиски с кола ще ти прилошее.

4. На 36 човека в Соббия им е прилошало заради жеzume.

Този аргумент е възможен и при съответните статични конструкции, но изразяването на стимула за новото състояние е присъщо най-вече на инхоативните предикати, тъй като те означават промяна в състоянието на експериенцера.

5 Глаголите застудява и захладнява имат отделна употреба без дателно местоимение със значение промяна в състоянието на околната среда (В сталта застудя; Времето застудя).

6 Относно семантичните роли, които приписват предикатите за физиологично състояние на своите аргументи, вж. (Джонова 2005: 574).

7 Примерите се цитират според оригиналния правопис. 
При инхоативните глаголи прилошее ми, призлее ли стимулът може да се представи като място или ситуация, която обичайно предизвиква съответното физиологично състояние. Тя се представя с предложна фрраза с предлога в (в кола, в $c a$ молет) или с израз от типа на при вида на $X$, при лисълта за $X$. За разлика от предлога om, който насочва към конкретен стимул за появата на даденото състояние, разглежданите конструкции представят обобщена, обичайна ситуация и това е причината съществителното в предложната фраза да е употребено генерично. Подобно изразяване на стимула за даденото физиологично или емоционално състояние не е възможно при съответните статични предикативни конструкции:

5. Прилошава ми при вида на лепило.

6. Прилошава му дори в плувен басейн.

7. Не беше от хората, на които им прилошава при вида на крьв.

За разлика от съответните статични конструкции при прилошее ми, призлее ми е възможно и наличието на адюнктна предложна фрраза с предлога $н a$, с която се представя мястото, на което се е появило описваното усещане:

8. Прилоша ми на тренировка сутринта.

9. Прилоша ми на една изложба.

Наличието на експлицитно изразен стимул прави възможна преносната употреба на инхоативните глаголи прилошее ми, призлее ми и олекне ми като предикати за емоция (вж. по въпроса за преносната употреба на предикатите за фризиологично състояние [Кустова 2002: 17]), като в тази употреба стимульт може да бъде изразен и с комплементно да-изречение (при призлее ми) или че-изречение (при олекне ми) (вж. [Коева 2019а: 65]):

10. На младока едва не му призлява от вгодушевление.

11. Тя не проумяваше, че от думите ѝ на него не му олеква, а му става още по-тежко. 
12. Не ви ли призлява да говорите за врелето?

13. Госпожице Нит, нялам дули да ви опиша колко ми олекна, че се излькнах от онази дупка.

При олекне ли аргументът локатив на душата, на сърието също насочва към емоционално, а не към фризиологично състояние: Олекна ми на душата.

Възможно е и изразяването на стимула с предложна фрраза с предлога от и местоимение (14) или съществително, чието съдържание се уточнява от атрибутивно съюзно изречение (Коева 2019б: 64):

14. Все оше му призлява от това, че САЩ не са успели да открият орғжия за масово унищожение.

Може да се обобщи, че при инхоативните предикати за физиологично състояние възможните аргументи са дателно местоимение експериенцер и предложна драза със семантичната роля стимул или локатив. При преносна употреба тези предикати означават емоционално състояние и в тази употреба стимулът може да се изрази с комплементно чеили $\partial а$-изречение.

\section{Глаголи за емоционално състояние}

Инхоативните глаголи за емоционално състояние дольчнее ми, дотғжее ми, дожалее ми, долилее ми, доскучае ми, докривее ли съответстват на статичните предикативни конструкции мъчно, тьжно, жал, мило, скучно, криво ми е. При тази семантична група инхоативи обектът на емоцията е изразен с непряко допълнение с предлога за подобно на съответните предикативни конструкции:

15. Така ще ил дотьжее за училище и като почнат на 20-ти януари ше са огън от любов.

Семантичната роля стимул се приписва на непрякото допълнение с предлога от или на комплементно изречение 
със съюза да (при дольчнее ми, долилее ли, доскучае ми) или че (при домьчнее ми, докривее ми). За сравнение при съответните статични предикативи стимулът може да се изрази само с подчинено изречение:

16. Радвам се, че не се сетих по-рано, толкова ми домъчнява от това!

17. Красиви истории. Да ти долилее да ги слушаш.

18. И тькло да ли докривее, че не мога да разчитали на приятелите си, чувал някой зад мен да брои.

19. Легнах при тебе, без да ти се обадя, защото ми дольчня да те събудя... ти така сладко спеше!

20. Те никога не бяха я виждали така хубава и малко ил дольчня, че ето сега ше я напуснат и надали някога ше се върнат в нея.

По отношение на предикативните конструкции за емоционална реакция или оценка Св. Коева посочва, че обектът може да се реализира с комплементно че-изречение, косвен въпрос или да-изречение, които се редуват с предложна група (Коева 2019а: 63). При инхоативните предикати също се откриват отделни примери с косвен въпрос:

21. ...че на човек да му дожалее колко може да деградира като военен министьр един български генерал от резерва...

Възможно е изразяването едновременно на обекта на емоцията с предложна фрраза с предлога за и стимула с комплементно изречение, като предложната фрраза е корефрерентна на аргумент от комплементното изречение. В следващия пример обектът на емоцията за прғстена е коредерентен на допълнението го в подчиненото изречение:

22. На певицата ѝ дольчня сало за пръстена, че ще трябва да го връша, но в името на другите се съгласи.

Св. Коева посочва подобна възможност при предикатите за предаване на информация и за знание, като разглежда 
случаите на експлицитно изразяване на обекта на знанието като вътрешна лява дислокаиия - явление, свързано с топикализацията на даден аргумент от подчиненото изречение в обектна позиция при главния предикат, като в същото време допуска и експлицитна реализация в подчиненото изречение (Чух го той да ми говори; Видяхле ги да ги водят) (Коева 2021: 14). Смятаме, че експлицитното изразяване на обекта на емоцията също трябва да се разглежда като случай на вътрешна лява дислокация.

Може да се обобщи, че инхоативните предикати за емоционално или фризиологично състояние означават ново състояние на експериенцера, изразен с дателно местоимение. В семантично отношение те съответстват на статични предикативни конструкции. За разлика от тях при инхоативните предикати за фризиологично състояние по-често се изразява аргументът стимул, като освен с предлога от той може да се въведе и с израз като при мисълта за, при вида на или в, който представя ситуация, която обичайно предизвиква съответното състояние. При предикатите за емоция стимулът може да се изрази с предложна фрраза или с комплементно изречение. Възможно е и едновременното изразяване на стимула и обекта на емоцията, като в този случай обектът на емоцията е коредерентен с аргумент от подчиненото изречение.

\section{Литература}

Джонова 2005 - Джонова $M$. Предикати със задължителен аргумент експериенцер от типа «дострашее ме», «домъчнее ми» // Littera scripta manet: сборник в чест на 65-годишнината на профр. д.ф.н. Василка Радева. София: Университетско издателство «Св. Климент Охридски», 2005. С. 568-577.

Иванова $1974-$ Иванова $К$. Начини на глаголното действие в съвременния български език / Бълг. акад. на науките. Инст. за бълг. език. София: Издателство на Българската академия на науките, 1974.

Иванова 2016 - Иванова E. Ю. Безличные предложения с обязательным местоименным выражением экспериенцера в болгарском 
языке // Архитектура клаузы в параметрических моделях: синтаксис, информационная структура, порядок слов / Моск. гос. пед. ун-т; Ин-т языкознания РАН; отв ред. А. В. Циммерлинг, Е. А. Лютикова. М.: Изд. Дом ЯСК, 2016. (Studia Philologica). С. 332-368.

Коева 2019a - Коева С. Комплементите в български // Доклади от Международната годишна конференция на Института за български език «Профр. Любомир Андрейчин» (София, 14-15 май 2019 г.). Сборникът се посвещава на 150-годишнината от основаването на Българската академия на науките / отговорни редактори: В. Мичева, Д. Благоева, С. Колковска, Т. Александрова, Х. Дейкова. София: Издателство на БАН «Проф. Марин Дринов», 2019. С. 57-68.

Коева $2019 б$ - Коева С. Типология на рестриктивните и нерестриктивните изречения в български // Български език. Приложение. № 66. 2019. C. $49-76$.

Коева 2021 - Коева C. Към типологичен анализ на комплементността в български // Доклади от Международната годишна конференция на Института за български език „Проф. Любомир Андрейчин“ (София, 2021). Сборникът се посвещава на чл.-кор. профр. д.ф.н. Емилия Пернишка по случай 85-ата ѝ годишнина и чл.-кор. профр. д.фр.н. Мария Попова по случай 80-ата ѝ годишнина / съст. С. Коева, М. Стаменов. Т. 1. София: Издателство на БАН «Профр. Марин Дринов», 2021. С. 13-27.

Кустова $2002-$ Кустова Г. И. О типах производных значений слов с экспериенциальной семантикой // Вопросы языкознания. 2002. № 2. C. 16-34.

Маслов 1982 - Маслов Ю. С. Граматика на българския език. София: Наука и изкуство, 1982.

Мурдаров 2016 - Официален правописен речник на българския език. Глаголи / ред. В. Мурдаров. София: Просвета, 2016.

Недялков 1987 - Недялков В. П. Начинательность и средства ее выражения в языках разных типов // Теория функциональной грамматики. Введение. Аспектуальность. Временная локализованность. Таксис / [А. В. Бондарко, М.А.Шелякин, В. С. Храковский, В. П. Недялков и др.; редкол.: А. В. Бондарко (отв. ред.) и др.]; Ин-т языкознания АН СССР. Л.: Наука, 1987. С. 180-195.

Радева 1993 - Радева В. Словообразувателна и семантична структура на деноминалните глаголи в съвременния български книжовен език. София: Университетско издателство «Св. Климент Охридски», 1993.

РБЕ 1977-2015 - Речник на българския език. Т. 1-15. София: Институт за български език, 1977-2015. URL: http://ibl.bas.bg/rbe/ (26.09.2021). 
Рожновская 1959 - Рожновская М. Г. Безличные предложения в современном болгарском литературном языке // Вопросы грамматики болгарского литературного языка / отв. ред. С. Б. Бернштейн. М.: Издательство АН СССР, 1959. С. 379-432.

Koeva et al. 2012 - Koeva S., Stoyanova I., Leseva S., Dimitrova T., Dekova R., Tarpomanova E. The Bulgarian National Corpus: theory and practice in Corpus design // Journal of Language Modelling. 2012. Vol. 0. No. 1. P. 65-110.

\section{Dative Inchoative Verbs in Bulgarian}

This paper deals with the syntactic description of inchoative verbs of physiological state or emotion that denote a new state obtained by an experiencer argument, where the experiencer is expressed as a dative pronoun. Semantically, these verbs correspond to stative predicative constructions. Based on the analysis of corpus and dictionary data, we come to the conclusion that the inchoative verbs under discussion take three arguments - physiological state predicates assign an experiencer, a stimulus and a locative role, whereas predicates of emotion take an experiencer, a stimulus and an object of emotion. In addition, we present conclusions regarding the syntactic properties of each argument, as well as observations on the frequency of expression of the different arguments, where relevant.

DOI: $10.31168 / 0459-6.08$

М. В. Ерлолова (Москва, Россия)

О соотношении двух плюсквамперфектов в псковских говорах в сопоставлении с инославянским материалом

Как известно, для части севернорусских говоров (прежде всего, архангельских) характерно использование плюсквамперфектных форм типа был, - $a,-o,-u+-л$-форма. Детально 